Review article

UDC: $61: 113 / 119(038)$

61:929 Еразистрат

DOI: $10.25106 / \mathrm{ahm} .2018 .2407$

\title{
Eduard Dajč
}

Scientific Society for the History of Health Culture

Bulevar Vojvode Mišića 41

11000 Belgrade, Serbia

E-mail: office@actahistorica.com

\section{PHYSICIANS AND PHILOSOPHERS THAT INFLUENCED ERASISTRATUS OF SAMOS}

\begin{abstract}
The aim of this paper is to shed some light on numerous physicians and philosophers that have influenced Erasistratus of Samos. His philosophy has numerous influences: (1) Alcmaeon's experimental approach to anatomy and physiology; (2) Heraclitus' philosophy of motion as a feature of life; (3) Leucippus and Democritus' atomism as the basis of cell theory in biology and medicine; (4) Anaximander's theory of evolution; (5) Empedocles' concept of bloodstream, resuscitation and his philosophy of medicine in general; (6) Anaxagoras' philosophy of medicine; (7) Philosophy of medicine of Erasistratus' immediate teachers: his father (also a physician), Metrodorus of Athens, Chrysippus of Cnidos, Herophilus of Chalcedon and Praxagoras; (8) Aristotle and Theophrastus' philosophy of biology and their methodology; (9) the philosophy of Epicurus; and (10) last but not least, the mechanics of the Alexandrian period. Out of all of these influences, I have analyzed in detail the first seven, since they are essential for understanding of Erasistratus' work. The other three are too extensive for this article, so I will refer the reader to the relevant literature.
\end{abstract}

Keywords: history of medicine, physicians

Non MeSH: philosophers, Erasistratus 


\section{Alcmaeon of Croton (around 500 BC) Father of scientific medicine}

Let's start with Alcmaeon of Croton, son of Peirithous, a pupil of Pythagoras of Samos, a refugee from Miletus who went to Croton when the Persians conquered his hometown. After all, the Milesian influence can be noticed in the name of his work, 'PERI PHYSEOS', which basically stands as the origin of scientific medicine. He particularly studied anatomy and physiology of the brain, cranial nerves and senses. Chalcidius ( $4^{\text {th }}$ century BC) claimed that he was the one who first performed eye surgery, but he was wrong since the physicians from Asclepions had had done this half a millennium before Alcmaeon. This is how Alcmaeon begins his work 'On Nature' ('PERI PHYSEOS'): "Alcmaeon of Croton spoke -concerning things that are not perceptible [and concerning mortal things] the gods have clarity, but insofar as it is possible for human beings to judge". [1] Therefore, Alcmaeon studied science, where he could make judgments from the signs that are presented, i.e. medicine, particularly anatomy and physiology. He was the first one to perform experiments on animals, and he came to a conclusion that the brain is the centre of life ("the brain is hegemonikon"). He wrote about the optic nerve and other cranial nerves, and performed eye surgery, as claimed by Chalcidius, and came to a conclusion: "All the senses are connected to the brain by nerves which, like channels and ducts (PORI) or passages (SEMITE), lead to cerebral cortex. Consequently they are incapable of action if [the brain] is disturbed or shifts its position, for [this organ] stops up the passages through which the senses act" [2]

Teophrastus' teacher, Aristotle, in his work 'On the Soul', said of Alcmaeon's explanation of the senses: (hearing): "Hearing is by means of the ears because within them is an empty space, and this empty space resounds... We hear by the empty space in the ears because this is what resounds when the air goes in, (because) all hollow cavities resound." Alcmaeon also discovered Eustachian tube (therefore it would be correct to call it Alcmaeon's tube). Aristotle continues: "Hearing is correctly attributed to emptiness, because air is thought to be emptiness, but the air makes sound when it continually reverberates as a separate unit.... (Smell): "Smelling is by means of the nostrils in connection with the act of respiration when one draws up the breath to the brain"... (Taste): "We distinguish tastes with the tongue"... (Vision): "Eyes se through the water round about. And the eye obviously has fire within for once one is struck it flashes out. Vision is due to the gleaming- that is to say, the transparentcharacter of that which (in the eye) reflects the object; and sight is the more perfect the greater the purity of this substance". Alcmaeon explains vision through triple sensation: "(1) outer world (environment), (2) wet interior of the eye and (3) inner light of the brain"... Alcmaeon continues: "Man differs from other creatures inasmuch as he alone has the power to understand. Other creatures perceive by sense but do not understand." [3] 
Alcmaeon of Croton can certainly be considered the creator of scientific medicine: he was the first one to form a scientific hypothesis and prove it by performing an experiment on an animal, and then publish a thesis 'On Nature' and expose it to public criticism and discussion, which is, along with money, fertile ground for scientific progress. [2]

Plato's 'Phaedo' is an excellent source for understanding Alcmaeon's philosophy since Simmias of Thebes', a participant in the dialectic, position on medicine comes from his (Simmias') teacher, Philolaus of Tarentum, and Philolaus' (position) comes from his teacher, Alcmaeon of Croton. Plato, i.e. Simmias, i.e. Philolaus, i.e. Alcmaeon says that sensations transferred to the brain through memory become experience, those then become ideas, and, finally, science. Simmias of Thebes (in Platos's 'Phaedo') continues:

"As the body is strung up like the lyre and held together by the elements of hot and cold, wet and dry, and the like (the basis for Alcmaeon's theory of isonomia), so the soul is the harmony or due proportionate admixture of them. And, if this is true, the inference clearly is that when the strings of the body are unduly loosened or overstrained through disorder or other injury, then the soul, though most divine, like other harmonies of music or of the works of art, of course perishes at once, although the material remains of the body may last for a considerable time, until they are either decayed or burnt. Now if anyone maintained that the soul, being the harmony of the elements of the body, first perishes in that which is called death, how shall we answer him?" [4] (Merciless words of a real physician, not very comforting for imprisoned Socrates.)

Alcmaeon's theory of isonomia can be noticed in the next quote from Plato's 'Timaeus'

"For as regards health and disease, and virtues and vices, there is no symmetry or lack of symmetry that is greater than that between the soul itself and the body itself... There is one protection for body and soul, and that is we should not move the body without the soul or the soul without the body, and thus they will be on their guard against each other, and be healthy and well balanced. And therefore the mathematician or anyone else whose thoughts are much absorbed in some intellectual pursuit, must allow his body also to have due exercise, and practice gymnastic; and he who is careful of fashion the body, should in turn impart to the soul its proper motions, and should cultivate music and all philosophy, if he would deserve to be called truly fair and truly good." [5]

Aristotle says in his 'Metaphysics' 
"In this way Alcmaeon of Croton seems also to have conceived the matter, and either he got this view from them (the Pythagoreans) or they got it from him...For he says most human affairs go in pairs, meaning contrarieties...Between those contrarieties the human body moves; If there's harmony between them- the body is healthy; if one (contrariety) is stronger- the body is ill. From this he (Alcmaeon) concludes that a physician is the one to restore the lost harmony". [6]

After Teophrastus, Plato and Aristotle, let's have a look at the words from Alcmaeon himself

"The bond of health is the equal balance of powers, moist and dry, cold and hot, bitter and sweet, and the rest, while the supremacy of one of them is the cause of disease; for the supremacy of either is destructive. Illness comes about (1) directly through excess of heat or cold, (2) indirectly through surfeit or deficiency of nourishment; and (3) its centre is either the blood or the marrow or the brain. It sometimes arises in these centers from external causes, moisture of some sort of environment or exhaustion or hardship or similar causes. Health on the other hand is the proportionate admixture of the qualities". [7]

In Plato's 'Symposium' the physician, Eryximachus says:

"The best physician is he who is able to separate fair love from foul, or to convert one into the other; and he who knows how to eradicate and how to implant love, whichever is required, and can reconcile the most hostile elements in the constitution and make them loving friends, is skillful practitioner. Now the most hostile are the most opposite, such as hot and cold, bitter and sweet, moist and dry, and the like." [8]

He (Alcmaeon) applies Heraclitus' "PANTA RHEI" theory in medicine and says:

"Life is motion, the motion of blood from the aorta to the brain, is interruption of motion- motion of blood in the brain ("cerebral death"), health is isonomiainner balance of continuous motion, disease is motion that disrupts the isonomia, everything is motion, disruption of motion or interruption of motion." [7]

\section{Alcmaeon's resume:}

1. Founder of scientific medicine

2. Introduced the notion of isonomia (=homeostasis)

3. Introduced the notion of idiosyncrasy

4. Claimed (proved) that the brain is the centre of the soul

5. Described the optical nerve and physiology of vision with the theory of triple sensation 
6. Described "Eustachian" tube

7. Noticed the importance of blood flow (but did not understand), as well as the difference between veins and arteries (but did not understand)

8. Made the connection between brain injury and functional disorder

9. The first one to scientifically define cerebral death (as total retirement of blood in the brain) and he claimed that sleep occurs by temporary withdrawal of blood

10. Named the content of nerves as "physic pneuma" (= neurite of the nerve cell), a term that Erasistratus took over

11. Described senses, etc.

\section{Fragments on Alcmaeon}

0.1. Alcmaeon, son of Peirithous, a pupil of Pythagoras [Diogenes Laertius], was the first one to write a work of natural science [Clement of Alexandria] (titled) "On Nature" [Galen of Pergamon]. [2]

0.2. Alcmaeon was the first one to state the difference between men and animals. (He) states that man differs from other creatures "inasmuch as he alone has the power to understand. Other creatures perceive by sense but do not understand"; since to think and to perceive by sense are different processes and not identical. $\mathrm{He}$ next speaks of the senses severally. Hearing is by means of the ears, he says, because within them is an empty space, and this empty space resounds. A kind of noise is produced by the cavity, and the internal air re-echoes this sound. [2]

0.3 . Alcmaeon says that we hear by the empty space in the ears, because this is what resounds when the air goes in because all hollow cavities resound. [2]

0.4. Smelling is by means of the nostrils in connection with the act of respiration when one draws up the breath to the brain. [2]

0.5. Alcmaeon says "that determination of tastes depends on the moisture and warmth which are inherent in the tongue in addition to its supple character". [2]

0.6. We distinguish tastes with the tongue; for being warm and supple it dissolves substances by its heat. [2]

0.7 . There are two narrow ducts containing psychic pneuma (neurites) ${ }^{1}$ and these ducts proceed from the seat of the brain, in which the highest, principal power of the soul is located, to the cavities of the eyes. And though these two ducts proceed for a while from a single point and from the same root, and are united for a while deep behind the forehead, they arrive at the concavity of the eyes separated like two roads, where the slanting cross-ways of the eyebrows extend. There the two ducts curve and, where the "lap" of the tunics receives natural moisture, they fill the eyeballs, which are protected by the covering of the eyelids and therefore are called "circles" (=orbitae). Furthermore, dissection is, to be sure, the primary teacher of the fact that the light-bearing ducts proceed from one location, yet this fact is understood

1 Compare to Erasistratus' psychic pneuma 
no less (by reason) from the fact that each eye moves together with (the other) and neither could move without the other. If someone wished to pursue the differences and individual qualities of these tunics, he will undertake a labour greater than the subject-matter proposed here. There are multiple transparent skins in front of the part that sees. Light is reflected by these transparent skins and "it is in this way that vision works". [2]

0.8 . All the senses are connected to the brain by nerves, which, like channels and ducts (PORI) or passages (SEMITAE), lead to cerebral cortex. Consequently they are incapable of action if [the brain] is disturbed or shifts its position, for [this organ] stops up the passages through which the senses act. [2]

0.9. Brain is what creates sense-perception (hearing, vision, smell and taste) which gives rise to the memory... and repeated memories of the same thing give rise to experience... and experience... provides the starting point of... science. [4]

0.10.For I suspect, Socrates (says Simmias of Thebes, a pupil of Philolaus of Tarentum, himself a pupil of Alcmaeon of Croton), that the notion of the soul which we are all of us inclined to entertain, would also be yours, and that you too would conceive the body to be strung up and held together by the elements of hot and cold, wet and dry, and the like, so the soul is the harmony or due proportionate admixture of them. And, if this is true, the inference clearly is that when the strings of the body are unduly loosened or overstrained through disorder or other injury, then the soul, though most divine, like other harmonies of music or of the works of art, of course perishes at once, although the material remains of the body may last for a considerable time, until they are either decayed or burnt. Now if anyone maintained that the soul, being the harmony of the elements of the body, first perishes in that which is called death, how shall we answer him? [4]

0.11.For he (Alcmaeon) says most human affairs go in pairs, meaning contrarieties... Between those contrarieties the human body moves; If there's harmony between them- the body is healthy; if one (contrariety) is stronger- the body is ill. From this he (Alcmaeon) concludes that a physician is the one to restore the lost harmony. [6]

0.12 . Alcmaeon says that the governing faculty is in the brain; through this we smell because it draws up the odours by the breathing. [2]

0.13. Alcmaeon of Croton, an eminent natural philosopher and the first one to dissect (live animals). [2]

0.14 . The question has not been solved among the authors, whether the offspring is born from the semen of the father only ${ }^{2} \ldots$ or from some seed in the mother as well, as it is held by Anaxagoras, Alcmaeon, Parmenides, Empedocles, and Epi-

2 This ancient belief that the offspring is born from the semen of the father only and that the mother is only a fertile ground, was the basis for justifying Orestes' killing of Clytemnestra. That is what tragic poets would use in a debate - agon in drama - to point out this "scientific argument" contrary to the fact of motherhood. 
curus. Considering the forming of the offspring, Alcmaeon admitted to not know much about it. ${ }^{3}[2]$

0.15 . From the fluid that surrounds the brain, its purest part is excreted through the passages leading to the brain membrane. [9]

0.16 . The male begins to have semen at about the age of fourteen complete. At the same time hair begins to appear on the pubes. As Alcmaeon of Croton says that flowers blossom before they bear seed. [10]

0.17 . Alcmaeon says that the fetus is nourished through the entire body. In fact, like a sponge, it takes up within it the nourishing parts from the food. [1]

0.18 . Concerning things that are not perceptible [and concerning mortal things] the gods have clarity, but insofar as it is possible for human beings to judge. [1]

\section{PHYSICIANS-PHILOSOPHERS THAT INFLUENCED ERASISTRATUS}

in fragments and comments

\section{Fragments on Heraclitus}

1.1. Heraclitus, [who was the] son of Bloson or, according to some, of Heracon, was a native of Ephesus. He flourished in the 69th Olympiad (around 504-501 BCE). [1]

1.1.A. And at last becoming a complete misanthrope, he used to live, spending his time in walking about the mountains; feeding on grasses and plants, and in consequence of these habits, he was attacked by the dropsy (ascites) ${ }^{4}$, and so then he returned to the city, and asked the physicians, in a riddle, whether they were able to produce a drought after wet weather. And as they did not understand him, he shut himself up in a stable for oxen, and covered himself with cow-dung ${ }^{5}$, hoping to cause the wet to evaporate from him, by the warmth that this produced. And as he did himself no go good in this way, he died, having lived seventy years. [1]

1.2. All things come into being by conflict of opposites, and the sum of things flows like a stream. [7]

1.3. Heraclitus is supposed to say that all things are in motion and nothing at rest; he compares them to the stream of a river, and says that you cannot go into the same river twice. [11]

1.4. Heraclitus removed stillness and inaction from everything- that was supposedly a feature of the dead. He attached movement to everything- eternal to eternal, transient to transient. [2]

3 Compare to Erasistratus' identical admission of his lack of knowledge in some field, something he often did- great scientists are rarely hesitant to admit their lack of knowledge, being aware of their limitations.

4 Erasistratus' clear explanation of the cause for ascites unfortunately wasn't familiar to our Diogenes.

5 A philosopher doesn't go to his death as a "madman" but as a humorous man - that too our Diogenes couldn't understand. 
1.5. A written composition should be easy to read and therefore easy to deliver. [12]

1.6. For knowledge of the truth, a man needs two tools - observation and reason. [2]

1.7. Heraclitus and the Stoics say that man begins to be mature about ... second seven-year period, round about which time the seminal fluid starts stirring. [2]

1.8. (Heraclitus: ) Things that can be seen, heard, and learned are what I prize the most. [2]

1.9. For the physicians, cutting and burning and trying all sorts of remedies, torture their patients, asking in addition a fee which they don't deserve, since they accomplish the same thing as the disease. [2]

1.10. Thus the vital heat proceeding from the sun gives life to all things that live. Subscribing to that opinion, Heraclitus gives a fine simile comparing the soul to a spider and the body to a spider's web. "As a spider", he says, "standing in the middle of its web is aware the instant a fly breaks any one of its threads and runs there swiftly as though lamenting the breaking of the thread; so a man's soul when any part of his body is hurt hastily goes there as though intolerant of the hurt to a body to which it is strongly and harmoniously conjoined." [5]

\section{Comments on Heraclitus}

His (Heraclitus') philosophy on movement is woven into Hellenic medical thought, and especially into Erasistratus' philosophy, as well as his insisting on the importance of observation and reason). What is also interesting is his philosophy on the connection between the soul and the body. His attitude towards the physicians of his day was what finally drove him to death. His insisting on easily read written compositions is in opposition with his (saved) writings, which is the reason for Aristotle's remark. His stance made influence on Hippocrates' medicine (first part entirely, second part somewhat), as well as Erasistratus' medicine (first part somewhat, second part entirely). Aristotle, without criticizing its essence, criticized the form of this opinion, having in mind unclearness that the absence of punctuation. He (Heraclitus) removed stillness and inaction from everything, saying that those were the features of the dead. Exactly this stance on movement is deeply woven into Erasistratus' philosophy of blood flow, digestion, uropoiesis, etc. Additionally, Heraclitus' stance on the importance of observation and reason for knowledge was of great influence. The connection of the soul, which according to Erasistratus, just like Alcmaeon, resides in the brain, "the leading hegemonikon", and the body, and comparison of the first with science and the latter with a spider web, had influenced Erasistratus, just like Heraclitus' stance that "everything changes and the only thing that is constant is change". It is the basis of Erasistratus' dynamic physiology. [13] 


\section{Fragments on Anaximander of Miletus}

2.1. Anaximander, the son of Praxiadas, was a citizen of Miletus. He used to assert that the principle and primary element of all things was APEIRON (the Infinity), giving no exact definition as to whether he meant air or water, or anything else. [1]

2.2. He wrote (books) 'On Nature, 'Rotation of the Earth', 'On Fixed Stars,' 'The [Celestial] Sphere', and others. [14]

2.3. (His) exposé (in books) he (Anaximander) organized by heads. [1]

2.4. Anaximander of Miletus, disciple of Thales, first attempted to draw the earth on a map. After him Hecataeus of Miletus... improved the work marvelously. [2]

2.5. Anaximander, a friend of Thales...claims that people must have originally been born from non-human creatures, on the ground that human (unlike animal) offspring require a long period of nursing and care in order to survive. If they had originally been born into the world from (and as) human beings, he reasoned, the species would have perished in the first generation. [2]

2.6. The animals came into being in moisture evaporated by the sun. ...Mankind was at the beginning ery like another animal, to wit, a fish. [2]

2.7. The first animals were produced in the moisture, each enclosed in a prickly bark. As they advanced in age, they came out upon the drier part. [2]

2.8. Anaximander... shown the fish to be the common father and mother of men. [2]

\section{Comments on Fragments on Anaximander}

His (Anaximander's) philosophy of "aperion" had influence on Hellenic thought and urged others to try and define what "apeirion" was. Leucippus and Democritus interpreted it as "atom" and set the atomic theory in physics, which is, along with cell theory ${ }^{6}$ in biology, the basis of Erasistratus' histo-anatomy. $\mathrm{He}$ (Anaximander) anticipated theory of development, so, in some way, he is the father of evolution and Oparin's coacervate theory, and (perhaps) the semi permeable membrane theory. [13]

Bertnard Russel in 'Wisdom of the West' humorously says:

"When it comes to the origin of man, Anaximander was of modern thought he noticed that the human child needs long nutrition and protection and came to a conclusion that man wouldn't survive if he was always the way he is now. So, he must have been different, that is, he must have generated from an animal that starts to take care of itself faster. This kind of proof is called reduction ad absurdum: disprove a statement by showing it inevitably leads to an impractical conclusion - in this case that man didn't survive. So, it has to be discarded.

6 Called atomic in Hellenic period and solidistic in Roman period. 
That means that he was different, which leads to some kind of evolutionary process. However, Anaximander wasn't satisfied with this proof. He stated that man originates from sea fish and proved it by observing the fossils and the way in which the shark nourishes its young. Evidently, that is why Anaximander forbids fish eating. Weather our brothers from the sea depths share the same tender feelings - remains unknown..." [15]

\subsection{Fragments on Empedocles of Akragas}

3.1.A Empedocles, as Hippobotus relates, was the son of Meton. [1]

3.1.B Empedocles was the son of Exaenetus. [1]

3.1.C Empedocles is the son of Archinomus. [1]

3.1.D (Empedocles) son of Meton. [14]

3.2. Heraclides of Pontus says that (Empedocles) explained to Pausanias about the woman who stopped breathing. Pausanias was, as Aristotle and Satyrus say, his beloved to whom he (Empedocles) also dedicated his poem 'On Nature'... Now, on the woman who stopped breathing, Heraclides says something like: "she kept her body for thirty days without breathing or decomposing". That is why he called Empedocles a doctor and a prophet... Of his (Empedocles) death there have been different stories. Heracldes said that Empedocles released (from the hospital) the woman who stopped breathing as alive and brought her sacrifice in the vicinity of Physianacos' property, hence his fame. [2]

3.3.A. Empedocles, the natural philosopher, by blocking up a certain mountain gorge, which permitted the south wind to blow a dire and pestilential draught down upon the plains, was thought to have shut plague out of his country (Acragant). [2]

3.3. B. Empedocles of Agrigentum was called "Checker of Winds." Accordingly it is said, that when, on a time, a wind blew from the mountain of Agrigentum, heavy and pestiferous for the inhabitants, and the cause also of barrenness to their wives, he made the wind to cease. [2]

3.4. A. This was his philosophy: there are four principles (elements), fire, water, air, earth, along with love to segregate things, and strife to aggregate them. [6]

3.4. B. Empedocles of Agrigentum, son of Meton, maintained that there were four elements: fire, air, water, earth, and two elementary powers, of which the former is a power of union, the latter of separation... For by "Zeus" he means the seething heat and the ether; and by "life-giving Hera" the air; the earth by Aidoneus and by Nestis and "the fountain-head of mortal life" the seed, as it were, and the water. [2]

3.4. C. Empedocles calls Zeus...the four roots of all things. [2]

3.4. D. Empedocles thought that, out of four immutable elements, complex entities originate, and those elements are intertwined so that when one would crush them into powdered iron or bronze rust... and (then) mixture them, he couldn't take one without the other in hands... Hippocrates was the first one that we know of that pointed out the mixture of the elements... There he differs from Empedocles, who 
also says that we and all entities on Earth originate from the same elements Hippocrates talks about, but not of the mixture (as Hippocrates claims), but of elements that in small parts come close and touch. [13]

3.4. E. Empedocles, Anaxagoras, Democritus, Epicurus, and all who (claim that) the Cosmos was compound of small particles of matter. [2]

3.5 Some of the earlier explorers included water too, for example Hero. I believe that they saw it in semen, because it is wet in all people. [3]

3.6. There used to be a slight competition of physicians of Kos and (those of) Knidos in who would have more inventions. [3]

3.7.A. Empedocles said that the light is body coming from a body that shines light and that it first travels or is at a given moment between the earth and its envelope, its movement being unobservable by us. [3]

3.7.B. There is a different opinion of those who say that the light is composed of small particles ejected by great pressure- that is an opinion, so it seems, of Empedocles. [2]

3.8.Empedocles says that there is some fresh water in the sea which is not visible but is nutritious for fishes. And of the natural cause of this fresh water you will find out from there (his writings). [2]

3.9. A. Empedocles claims that of all living creatures, plants were the first ones to grow from the ground. [2]

3.9. B. Empedocles is wrong in adding that growth in plants is to be explained the downward rooting by the natural tendency of earth to travel downwards. [3]

3.10. Certain sophists and physicians say that it is not possible for anyone to know medicine who does not know what man is and that whoever would cure men properly, must learn this in the first place. [7]

3.11. Empedocles says that first generations of animals and plants were not born with all their parts. [2]

3.12. Empedocles says that the first breath of a newborn comes when liquid rushes out from the womb, and when after that the outer air enters the void through little openings, and when the natural warmth, with its tendency to go out, pressures the air, the breath is created. From that moment, the blood flows towards the surface and its circular movement ${ }^{7}$ pushes the air through the pores, and when it goes out the breathing out happens, and when it (blood) goes back and floods the space it once left, the breathing in happens. Empedocles mentions clepsydra here. [2]

3.13. According to Empedocles, living creatures feed through assimilation of the matter that suits them, grow because of the warmth, and weaken and decay because of the absence of both. Also today's people, in comparison with the ones before them ${ }^{8}$ (first people) are in the same position as unborn fruit in the womb. [2]

7 Clear concept of blood circulation- blood flow, which was once explained through the theory of the tide

8 Clear concept of evolution and naming "the first people". 
3.14. Empedocles says that there is one nature of bone... if all bones have the same proportion in their mixture there should be no difference between the bones of horse, lion, and man. [16]

3.15. The umbilical cord is composed of vessels, four in number, two venuous, ${ }^{9}$ two arterial, through which nutritive material, both blood and breath, is supplied to the embryos. ${ }^{10}$ [2]

3.16. Empedocles says that monstrosities are born from excess or deficiency of the semen (= fertilized egg)... because of its division into multiple parts. So, it seems that he envisioned all causes. [10]

3.17. How much time it takes for a living being to form in the uterus? Empedocles says that, in men, the formation of limbs starts at day thirty six and is finished in detail by day fifty. ${ }^{11}$ [2]

3.18. Where do differences between parents and ancestors come from? Empedocles says that similarities come from the semen (= fertilized egg) and differences from the heat evaporation of the semen. [10]

3.19. Parmenides, Empedocles and Democritus say that mind and body are the same, and according to them no human being could be described as unreasonable. [2]

3.20. He (Empedocles) says that hearing results from sounds within (the head), whenever the air, set in motion by the voice, resounds within. For the organ of hearing, which he calls a "fleshy off-shoot", acts as the "bell" of a trumpet, ringing with sounds like those it receives. When set in motion (this organ) drives the air against the solid parts and produces there a sound. [2]

3.21. By following Empedocles they say that one type (of frenzy) comes from the cleansing of the soul, and the other from derangement of the soul caused by something in the body or some imbalance. I want to write about this frenzy- The Greek call it mania. [2]

9 For the first time clearly naming three important terms (A) blood vessels, (B) arteries, and (C) veins, which is the terminology taken later by other physicians, among them Erasistratus.

10 For the first time clearly explained that arteries bring (to the embryo) food and air through blood, and veins drain away blood. There is no mention of any "hollow blood vessels which contain air (arteries), while the blood is only in veins" as some superficial medical historians believed. They explained this error of theirs by saying that the Hellenic physicians allegedly would find, on autopsy, arteries empty and blood clots only in vein. This was utterly stupid (of superficial historians) taking into account that, as Galen says, " every butcher is aware of blood circulation when he slaughters an animal by cutting the neck artery and blood gushes until it drains away".

11 Clear concept of embryology. It is only unclear whether Empedocles performed experiments on embryos. To this sensitive question nobody could give clear answer. 


\section{Comments on Certain Fragments Concerning Empedoles' Philosophy Particularly in Medicine and Physics}

Fr. 3.2. - He can be called "the father of resuscitation" since he kept a woman who stopped breathing and without pulse, alive for thirty days and released her home healthy!

Fr. 3.3. A. - He helped put a stop to malaria epidemic (not plague). Therefore, he was perfectly aware of the influence of the environment on health.

Fr. 3.4. A-E. -His (Empedocles') philosophy of four elements had a substantial influence on the Greek thought. From this, Hippocrates sets his theory the four humors.

Fr. 4.4. E. - "Stars and atoms"- the (great) Cosmos is compound of small particles. [13]

Bertnard Russel, of the theory of four principles, says:

In order to compromise between Eleatic philosophy and everyday obviousness of perception, Empedocles accepted all of principles once considered basic, but he added four of his own (to Thales' water, Anaximenes' air, and Heraclites' fire, Empedocles' added earth and completed the system), and all together named "roots of things". Aristotle later named them "elements" ("stoiheia" = component parts, "principles"). The philosophy of four elements dominated chemistry for almost two thousand years, and its traces can be still found today in modern language- when we speak of "furious" elements. This philosophy is the basis of two pairs of opposites: dry and wet, and warm and cold...Besides, there must have been something that made the basic elements mixture differently- according to Empedocles those were two active principles love and hate (forces of attraction and repulsion). Their only ask is to unite and separate. However, considering that the idea of non-substance activity still hadn't been known, they were the ones to serve as substances, so along with the first four, they were now six in total. When the first four substances are separated, hate takes the space among them. And when they are united, love keeps them together. It can be noticed that the theory that initiator has to be material can be somewhat justified. Although this theory has been more elaborated, in modern science, it is still believed that the activity has to have some kind of substantial source..." [15]

It is important to hear Russell's comment to understand the significance of Empedocles' philosophy of medicine. Based on this, Hippocrates formed his philosophy of four humors which is the basis of the theory of humors which was, for more than half of a millennium, in opposition to the cell theory (=atomic) of Leucippus and Democritus' followers in philosophy of medicine, i.e. Erasistratus and his followers, which has, unfortunately, become generally accepted.

In the same book, Russell talks about Empedocles like this:

“... I have to mention Empedocles' interest in medicine and physiology. $\mathrm{He}$ adopted the philosophy of Alcmaeon of Croton, a follower of the Pythagoreans, that 
health is an utter balance (isonomia) of opposite components, and that disease happens when one of them outweighs the other. Similarly, he adopted (Alcmaeon's) philosophy of pores or passages through which the body breathes ("skin respiration"). Those pores enable sense perception. Particularly his philosophy of sight, which had been considered valid for a long time, describes the connection of the light from the observed object and the fire from the eye." [15]

Fragments that touch upon his birth (i.e. confusion about his father's exact name) and his death are proof of his fame while he was still alive, the one he gained when he controlled changed the climate ("the wind-stopper") and brought back to life that woman. The latter is of particular importance for us (physicians), since he is considered to be "the father of resuscitation". It is important that the testimony of case of the woman who stopped breathing ("And concerning the woman who stopped breathing, Heraclides (of Pontus) says that she remained alive for thirty days without pulse or breatahing") comes from a very reliable witness, astronomer and mathematician, Heraclides of Pontus (388-310. B.C.), who was the first to prove that the Earth rotates on its axis and that it (the rotation of the Earth) causes day and night. He (Heraclides) proved that Hermes (Mercury) and Aphrodite (Venus) revolve around the sun, and that way set the "Tycho de Brahe-an" theory long before Brahe himself (the same as, much later, Aristarchus of Samos set a "Copernicusian" theory long before Copernicus himself). Therefore, Heraclides can be trusted, so it can be confirmed that Empedocles was the first (in the West) to perform cardiopulmonary resuscitation and intensive care and kept a patient, with no pulse or breathing, alive for over a month, and released her from the hospital. If this was the only thing Empedocles had done, it would have been enough to earn him a place in the history of medicine. Diodorus of Ephesus says of him: "...When, because of odorous vapors from a nearby river, some hideous disease spread over Selinuntians... Empedocles paid (he was rich enough) to have two neighboring rivers brought, and those rivers, after they had mixed, became healthy. "This proves that Empedocles was aware of, not only ontological-cosmological importance, but also epidemiological importance of water (aforesaid Diodorus of Ephesus) and air, and this was also accepted by Hippocrates. [13]

It is important to mention Aristotle who speaks about the significance of scientific discoveries in medicine - their number and value. However, while the first is a quantitative indicator and completely objective (for evaluation), the latter is qualitative, so predominantly subjective (for evaluation, which is always personal). Therefore, the first (number) remained to this day the basis of evaluation of scientific work, i.e. not the significance but the scope of the work. [13] 
$\mathrm{He}$ (Empedocles) noticed the enormous speed of light ${ }^{12}$ and sets corpuscular theory of light. ${ }^{13} \mathrm{He}$ (Empedocles) pointed out that plants were the first on land, and that gravity makes the root of a plant grow downward. Although Hippocrates believes that physicians do not need to dabble in all fields, he (Hippocrates) still comes to a conclusion that only a physician can gain the knowledge of nature. [13]

Not only was he (Empedocles) the first one to discover skin respiration, but he was also the first to describe in detail lung respiration, particularly the first breath of a newborn, and then the second. This fragment for us (science and medicine historians) is of great significance because it is the first to mention that the blood flow is actually circulation of blood, but it is interpreted by most of science historians as so-called "theory of tides" because of his (Empedocles') note "and when it goes back". They did not realize that this was a part of description of the first breathing in and out and a general theory of philosophy. The clear Empedocles' claim about the circulation of blood and his (Empedocles') claim that "the blood starts and finishes its motion in the heart" was interpreted as the motion of a pendulum and the tides. What is interesting is that not only is his (Empedocles') clear mentioning of blood movement is not attributed to him, but also "the theory of tides", which is attributed to Galen, even though Galen himself says that "every butcher is aware of blood circulation". It is clear that Empedocles is for the theory of circulation (of blood), what Anaximader is for the theory of evolution (of living beings), and Erasistratus is for the theory of circulation what Darwin is for the theory of evolution. Therefore, Empedocles and Anaximander set out the problems in theory (deductive reasoning), and Erasistratus and Darwin practically solved the problems with irrefutable evidence (inductive reasoning). He (Empedocles) clearly distinguished between two types of veins that carry blood in and out of heart (veins and arteries). However, it is important to mention that the Hellenic physicians, from the time of Alcmaeon of Croton, distinguished between veins (which they called "veins through which dark blood flows") and arteries (which they called "veins through which light blood flows"). The cause of confusion, which I described in detail in the part of introduction concerning ancient terminology, was that what they called "veins" (their term) were blood vessels (our term), and what they called arteries (their term) were actually airways (our term), i.e. the trachea, bronchi and bronchioles (their and our terms). Therefore, the science and medicine historians have believed wrongly that they (ancient physicians) thought that "inlet veins" (=arteries) were filled with air because (when performing autopsy) they were found empty, while "let-off veins" (=veins) were full of scorched blood. When you consider that vivisection of animals have been performed since the time of Alcmaeon, and vivisection of people (actually, criminals sentenced to death, which

12 And claims that it is the final, highest speed which was confirmed by a Dane Roemer, 22 centuries later, in 1676.

13 Almost 2.5 millennia before Isaac Newton. 
are, at the order of the king, ${ }^{14}$ surrendered to physicians and not executioners) since the time of Herophilus of Chalcedon and Erasistratus, we can see the absurdity of this claim, especially if we have a look at how Erasistratus described the transfer of oxygen and food through blood:

"...Through membranes of lung capillaries, the air enters the blood from (lung) alveoli, it is somehow combined with the blood ${ }^{15}$ and it feeds the organism the same way as digested food, through blood, reaches all atoms (=cells) and new connections are made in accordance with the organ the atoms (=cells) are part of. Necessary for the life of atoms (=cells) and the organs they make, as well as the whole organism, are the air ("which is somehow combined with the blood") and food (the components of which are dissolved in blood"), which are delivered through "inlet veins" (=arteries)". [13]

Erasistratus continues with a clear description of deliverance of "clear part of blood" (=plasma) into interstitial compartment, through "very little blood vessels" (=capillaries). [13]

Other fragments of Empedocles are either commented in footnotes, or are clear on their own and do not require additional comments but only admiration. However, it should be mentioned that "semen" (in frag. 3.16.) means "fertilized egg cell" and this where Aristotle ("the father of embryology" if Empedocles is its "grandfather") saw the accuracy of his (Empedocles') claim ("that that monstrosities are born from excess or deficiency of the semen"). Therefore, Empedocles can be considered the originator of embryology ("grandfather") and Aristotle its founder ("father"). [13]

It is also important to mention that Aritotle's term "spermatozoide", as well as the term of Aleksandar Dj. Kostic, "semenoglavac", has the same meaning (for that male cell that carries the genetic information of the father). I call this "tailed androzone"16, since it is neither "sperm", nor "semen". [13]

He (Empedocles) noticed the labyrinth of the inner ear (fr. 3.20.), as well as the connection of mental disease with bodily causes (fr. 3.21.). "Oh, you are wise Empedocles, and glorious is the town where you were born!" [13]

\section{Fragments on Anaxagoras called "Nous"}

4.1. They say that in the year of the seventieth Olympic Games Democritus (called "Atom") and Anaxagoras (called "Nous"), philosophers of nature ("naturalists"), were born, and with them also Heraclites called "the Dark". [2]

4.2. Afterwards, his father entrusted him (Democritus) to Leucippus, and to Anaxagoras ("and so atomism was born")... [1]

14 A decree of Ptolemy I Soter

15 Prediction of oxyhemoglobin

16 i.e. "androzoid" 
4.3. Anaxagoras of Clazomenae, whom his contemporaries called "the Mind" because they admired his sharp mind, and it proved to be great in the philosophy of science... [4]

4.4. Alcaeon of Croton, son of Peirithous, was the first to write "On Nature", and others claim that Anaxagoras of Clazomenae, son of Hegesibulus, was the first to publish a book with drawings (i.e. first scientific illustrated book). [2]

4.5. Now let us also search into the homoeomeria of Anaxagoras, as the Greeks term it, though the poverty of our country's speech does not suffer us to name it in our own tongue; nevertheless the thing itself it is easy to set forth in words. Firstwhat he calls the homoeomeria of things-you must know that he thinks that bones are made of very small and tiny bones... and blood is created of many drops of blood coming together in union... [2]

4.6. But those who make the elements infinite in number, as Anaxagoras and Democritus do... Further, Anaxagoras held that any part is a mixture in the same way as the All, on the ground of the observed fact that anything comes out of anything. For it is probably for this reason that he maintains that once upon a time all things were together. (This flesh and this bone were together, and so of any thing: therefore all things: and at the same time too.). For there is a beginning of separation, not only for each thing, but for all. Each thing that comes to be comes from a similar body, and there is a coming to be of all things, though not, it is true, at the same time. Hence there must also be an origin of coming to be... So necessarily all things must have been together at a certain time, and must have begun to be moved at a certain time. [17]

4.7. Anaxagoras of Clazomenae, son of Hegesibulus, posits as elements the 'homoeomeries'... The hardest question, it seemed to him, was how anything can come out of not-being or can corrupt into not-being. We take simple food, bread and water, and with it we feed hair, veins, nerves, bones and other parts (of the body). Therefore, we have to admit that food consists of all productive parts of the blood bones, nerves and others. Those parts can be considered the mind. This shouldn't be connected to sense perception; water and bread do not create this. However, little parts can be seen in them, the components ("MEPOI" pl.) are equal in food ("OMEOI") to what is being produced; therefore (Anaxagoras) named them homoeomeries ("OMEOIMEPOI") and claimed that they are elements, and that homoeomeries are matter... [18]

4.8. Anaxagoras (said) that the matter is infinite but that out of it (come) little parts which are similar to each other. [2]

4.9. (Those) who make the matter of things more than one, as Empedocles, Anaxgoras, and Leucippus... [18]

4.10. They (Anaxagoras and others) prove that the air is something real- by compressing mixtures and also closing it within clepsydras... [17]

4.11. ... For what happens with clepsydra the true cause is what Anaxagoras says: "the air within it is the reason the water is not coming in when the pipe is closed". [19] 
4.12. Why is the night better to receive noises than the daytime? Is it because, as Anaxagoras say, the Sun warms the air during the day so it squeals and screeches, and it is still at night for the lack of heat? [19]

4.13. That he (Anaxagoras) spoke recently that the Moon is light because of the Sun... [11]

4. 14. ... Anaxagoras and Democritus (claim that the Moon) is a solid body with its own valleys, mountains and abysses. [2]

4.15. The pupils of Anaxagoras and Democritus say that the Milky Way is the light of many stars. [20]

4.16. Anaxagoras thinks that the rainbow is the reflection of the sun's brightness from thick cloud. And in a similar way he accounts for the so-called parhelia, which take place along the Pontos. [2]

4.17. On the sea, of its origin and why it is bitter, Anaxagoras says that when the moisture which was at first gathered in pools was burned all around by the revolution of the sun, and the fresh water was evaporated into saltness and bitterness, the rest (of the sea) remained. [2]

4.18. (On the cause of the floods of the river Nile) Anaxagoras says that it comes from the snow in Ethiopia which melts in summer and freezes in winter. [2]

4.19. Anaxagoras says that that melted snow from the mountains of Ethiopia comes as far as the Nile. All the elderly thought the same. [2]

4.20. Anaxagoras (says that) ... with most this contrast of hue with that of the pupil occurs by day, but with some by night, and this is why the latter are keen of vision by night. But, in general, night the rather is of the eye's own hue. Furthermore, there is reflection by day, he holds, because the light is a contributing cause of reflection, and because the stronger of two colors is regularly reflected better in the weaker... Hearing depends upon the penetration of sound to the brain, for the enveloping bone which the sound penetrates is hollow... by our experience when an impression long persists and when is present in excess we cannot long endure. [2]

4.21. Anaxagoras says that all living creatures have active minds, but it is as if they do not have passive mind, called interpreting mind. [2]

4.22. Anaxagoras says that man is the most reasonable of all creatures because he has hands (connection to F. Engels's 'The Part Played by Labour in the Transition from Ape to Man'...) [21]

4.23. Anaxagoras and many others think that the food is supplied through the umbilical cord. [9]

4.24. After Anaxagoras and Diogenes had said that all living creatures breathe, they spoke about the way fish and shellfish breathe, and Anaxagoras said: "The fish breathe when they let off water through gills...by breathing in the air created in the mouth". [10]

4.25. Pupils of Plato, Anaxagoras and Democritus think that the plants are animals growing from the ground. [2] 
4.26 Anaxagoras says that the air contains the seeds of all things, and that they, when carried to the ground, together with water, give birth to plants... Even though Anaxagoras said that a plant has breathing (i.e. the plants breathe), the element of the food for the plants come from the ground, while the elements of giving fruit come from the Sun. Therefore, Anaxagoras said... that the ground is the mother of plants and the Sun is the father. [2]

4.27. Anaxagoras, in his first book 'On Nature', says clearly that the existence and decay are actually composition and disintegration. He writes:

"On existence and decay Hellenes think rightly because nothing comes to life nor does it decay, but it is composed from the existing things (i.e. those from which it became) and disintegrated again. So it would be right to call existence composition and decay disintegration. [2]

4.28 The greatest philosopher of nature (i.e. the greatest naturalist!), Anaxagoras, criticizing the weakness of vision, says:

"Because of their weakness I couldn't reason (i.e. make out) the truth."

$\mathrm{He}$ (Anaxagoras), says that the proof of their unreliability is a slight change in color. If we should take two colors, black and white, and drip from one to the other drip by drip, we wouldn't be able to differentiate between little phenomena, even though they exist in nature. [2]

4.29. There is a method for understanding unclear things: "Looking for hidden things with the help of actual things". Thus spoke Anaxagoras and thus was praised by Democritus. [2]

4.30. So-called "bird milk" is egg white. [7]

\section{Comments on Fragments on Anaxagoras}

An exuberant Ionian naturalist and a physician from Clazomenae (located on the South coast of the Gulf of Hermos- Phocaea being in North and Smyrna deeper on mainland), came to Athens, after he had retreated before the Persians, and became a teacher and a friend of Pericles. From Eusebius' Chronicle comes a romantic assumption that the great three - Democritus, Anaxagoras and Leucippus, were born in the year of the $70^{\text {th }}$ Olympic Games. Even if that wasn't true, they were still friends and associates on the same great goal- describing and explaining nature.

It is interesting to notice that great Hellenic scientists were much friendlier with each other than the scientist nowadays, whose occasional meetings in scientific conventions are more acts of formality than of collaboration, because they (scientist nowadays) cooperate only with their superiors and subordinates, i.e. sponsors and associates (and they communicate solely online). This exactly is the reason why today's science is poor and boring (especially history of science, because the mistakes of the predecessors are copied), even though the scientist are not boring themselves. They are witty people, just like before, but with poor communication they exercise their wit in small circles. If they were to meet more often and in different ways, more 
casually, like writers and poets, their influence on the younger generations would be greater. [13]

Just as Alcmaeon was the first to publish a piece of work with a title that would become common, almost necessary for the work of any serious scientist ("PERI PHYSEOS"- "On Nature"), Anaxagoras, according to Clement of Alexandria, was also the first one to publish a book with illustrations, which would become common afterwards and is still today (in scientific books). As far As Anaxagoras' nickname is concerned, we can chose, according to our own inclination, between Plato's or Iriney's prologue. ${ }^{17}$ Socrates, himself, accused of being an infidel, told the judges: "The positions I am being judged on are Anaxagoras', and every citizen of Athens can buy them for one drachma”. [13]

B. Russell says about him (Anaxagoras):

"Anaxagoras mainly dealt with scientific and cosmological questions. There is at least one piece of evidence of him as an insightful observer (of nature) ${ }^{18}$ : in 468467 B.C. a big piece of meteorite rock fell into the river Egos Potam, and, without a doubt because of it, Anaxagoras partly developed his opinion that the stars were made of incandescent rocks". [15]

Despite many Anaxagoras' friends of influence in Athens, because of narrow-minded conservatives of Athens, every independent and unpopular opinion was suspicious, even in the best of times... It seems that this hasn't changed in the last 2500 years. Anyway, Anaxagoras was convicted of atheism and medism (i.e. impiety and preference towards the Persians, even though they were the ones that banished him from his home), since it is always convenient to label somebody as a "traitor of God and homeland" if their philosophy can't be refuted. It is not known what sentence he got and how he escaped (since he was a real, wise scientist- naturalist, and not philosopher-ethicist as Socrates), but it is suspected that Pericles helped him. After this, he (Anaxagoras) went to Lampsac and continued with his work until his death 424. B. C. His philosophy, ${ }^{19}$ as well as Empedocles', was a new attempt at interpreting Parmenides' criticism. While Empedocles thought of every part of pairs of opposites (warm-cold, dry-wet...) as basic matter, Anaxagoras thought that every one of them, in different ratio, is the content of every part of matter, no matter how small. In order to prove his claim he relied on infinite divisibility of matter. He (Anaxagoras) says: "A lot of splitting of things into smaller parts does not lead, in the end, to something different, because Parmenides proved that what is cannot stop being (what it is) nor can it become something else (i.e. what it isn't)... Differences between things are caused by the dominance of one or the other opposite." Anaxagoras would say that even snow is, to a certain measure, black, but that the white is dominant- there is a

17 i.e. he can be called either "mind" or "infidel".

18 Compare with Galen's remark on Erasistratus: "What else do they do but observe the nature and its effects" [13]

19 Science (physics) 
little of Heraclitus in this. The opposites keep together and everything can change into another. Anaxagoras says that "in everything there is a part of everything except for "nous" (since whenever dealing with the question of matter he would mention nous, he was given the nickname "Mind"). It is his effective principle ("nous") that stands instead of Empedocles "love-hate". However, he considers it to be a substance, although very rare and hardly noticeable. Nous is different from other substances in its purity. Nous is what makes things move. Moreover, depending on whether it is there or not, there is a difference between animate and inanimate. On the origin of our world he had a similar opinion as we do: "Nous starts the vortex somewhere and as it (vortex) grows stronger, different things separate from it according to whether they are more or less massive. Heavy pieces of rock, thrown out by the rotation of the Earth, move farther away than other objects. Because of their high speed, they start to glow and that explains the nature of the stars (i.e. meteorites, as we would say)." As all Ionians, he thought that there were many worlds. $[13,15]$

Russell explained, in the quote above, Anaxagoras' theory of "homoeomeria" or, more exactly, "omiomeria" (so we could explain Lucretius' comment, with perfect words of Aristotle, that the "components" (MERI) are "equal" (OMIOI)). He (Anaxagoras) was, just like his predecessors, Anaximander and Empedocles, a evolutionist, i.e. a biologist who was perfectly clear that "all creatures breathe". He described gill breathing of not only the fish but also shellfish, and plants. It is particularly significant that he was perfectly exact in interpretation of plant physiology: "They need air for breathing; they get food from the ground, elements of bearing fruit from the Sun". With this, not only did he indicate the breathing of plants, but also, in a way, photosynthesis. He also clearly described "the flow of matter" and gave the final answer to a kid's question at the grocery "what is "bird" milk". He gave evidence for materiality of air and explained seeing the colors, and the difference between day and night vision suggested rods and plugs (second part of the same fragment). His comments on hearing the sounds are still anthological. The comments on astronomy are perfectly exact. He suggested that the Moon was a solid body with its own valleys, mountains and abysses and that it passively glowed with sunlight, and that the Milky Way was the light of many stars. The rainbow is a reflection through aerated water ${ }^{20}$, and he similarly interpreted parhelia. He was a paleoclimatologist and a hydrogeologist because he interpreted the creation of the sea and periodical flooding of the river Nile. Anaxagoras was the first to point out the importance of hands in brain development. The "part played by labor in the transition from ape to man" is Anaxagoras' and not Engels's concept. When it comes to perception, Anaxagoras further developed the biological principle, valid in physiology of senses even today, according to which sense perception depends on the contrast, and very strong sensation first cause discomfort and then pain. In general, Anaxagoras, called "the Mind", "infidel", was a naturalist "par exellance". [13]

$20 \mathrm{He}$ noticed that the white sunlight is complex and it contains the whole rainbow spectre of colours. 


\section{Fragments on Leucippus}

5.1. Leucippus was a native of Velia ${ }^{21}$, but, as some say, of Abdera ${ }^{22}$; and, as others report, of Melos. ${ }^{23} \mathrm{He}$ was a pupil of Zeno... a teacher of Democritus. [2]

5.2. Leucippus of Velia or Melos, acquired the philosophy of Parmenides, but didn't take Parmenides' or Xenophanes' way, when it comes to interpretation, but, it seems to me, he did the opposite. While they (Velians) described the universe as one and motionless, unborn and limited, and they didn't allow for non-being to be analyzed, he (Leucippus) took atoms as elements, infinite in eternal motion. $\mathrm{He}$ thought they existed in many shapes because he saw that generation and change repeat constantly in things, with being not existing any more than non-being ("cosmos includes empty as well as full"), and that both are the reason for things that come to life. By seeing the substance of atom as compact and full, he said that this is being and that it moves in the emptiness he called non-being. However, he claimed that it (emptiness) exist no less than being. Similarly, his friend, Democritus, spoke of emptiness and fullness as elements. [2]

5.3. Democritus and Leucippus claimed that everything consisted of invisible little bodies, and that those (bodies) were infinite in number and shapes, and that things differ according to those bodies of which they are complied, and according to their order and position. Democritus and Leucippus created shapes with which they could explain generation and change by separation and joining, (as well as) creation and corruption by (waiting for) order and the position of change... by changing its content, the same object seemed opposite to different characteristics, and it changed place if a little fraction was added, and if only one changed place, than it seemed totally different. Even comedy and tragedy are derived from the same letters. [18]

5.4. That was Democritus' shameful philosophy, and Leucippus' before him, that there were little bodies (of different shapes) from which Heaven and Earth were created, without any force from the nature, but accidentally, and this philosophy was brought to our time by you, Gaius Velleius!

5.5. Leucippus, Democritus and Epicurus (all of them atomists) thought that the sense of vision was created by penetration of pictures. [2]

5.6. Democritus says that vision is receiving a picture of the object of looking. The picture is an image in the pupil just as in other transparent substance that can keep a picture... He (Democritus), and Leucippus before him, and Epicurus' successors later, thought that the cause of vision were some pictures of the same shape as the things that are being looked at, and from them they would constantly fall out and fall in the eye. [2]

5.7. To what does death belong- body or soul? Leucippus says that... those are the states of the body and not soul. [2]

21 Because of Zeno, his teacher.

22 Because of Democritus, his pupil.

23 Because of Anaximander, his predecessor. 


\section{Comments on Fragments on Leucippus}

Leucippus of Melos "took atoms as elements, infinite in eternal motion"... and that (atomistic) philosophy is a compromise between Velian monism and Ionian pluralism. Aristotle interpreted the philosophy of Leucippus on the same atoms giving different shapes and spoke beautifully: "Even comedy and tragedy are derived from the same letters." He (Leucippus) explains the theory of vision with pictures that penetrate from outside and create images on the pupil (and then arrive, the way Alcmaeon described, to the brain- "the ultimate hegemonikon", that sees them). Of death he says that it is a state of the body (just like Alcmaeon), and mentions no soul. [13]

\section{Democritus of Abdera 470-375 BC}

Democritus of Abdera, a naturalist and a physician. He perfected atomistic philosophy of his teacher Leucippus, in physics as well as in biology (which is actually the philosophy of cell), in such a consistent, thorough and wise way that Aristotle says that everybody else was superficial in dealing with it (the problem), except for Democritus, because he wouldn't miss a thing. The upcoming fragments are only the ones of biological-medical nature.

\section{Fragments on Democritus}

6.1. Democritus was the son of Hegesistratus, but as some say, of Athenocrites, and, according to other accounts, of Damasippus. He was a native of Abdera, or, as it is stated by some authors, a citizen of Miletus. [1]

6.2. He and Socrates were both born in the year of 77. Olympic Games (472469 B.C. $)^{24}$, some say in $80 .{ }^{25} \mathrm{He}$ was a native of Abdera in Thrace, a pupil, according to some, of Anaxagoras and Leucippus... His pupils were Anaxagoras and the physician, Hippocrates. ${ }^{26}$ Democritus was also called a mocking bird because he would mock people's vanity. Two books are certainly his: 'Great World System' and 'On Nature. [14]

6.3. His philosophy was this: Elements of everything are atoms and void, everything else is subjective. The worlds are infinite, born and corruptible. Nothing comes from non-being and nothing decays into non-being. [1]

6.4. Wise men would never be in anger, but: Heraclites - in tears, Democrituslaughter! [7]

6.5. Of his books, Thrasylus has given a regular catalogue, in the same way that he has arranged the works of Plato, dividing them into four classes... These are

24 Or more exactly, in the third year of 77 . Olympic Games (470 B.C.)

25 i.e. $460-457$ B.C., which is, naturally, too late.

26 The relation between Hippocrates and Democritus drew a lot of attention in the old days, therefore, a lot of novels were written about them. [7] 
his writings on natural philosophy. The Great World (which Theophrastus asserts to be the work of Leucippus); the Little World; the Cosmography; a treatise on the Planets; the first book on Nature; two books on the Nature of Man, or on Flesh; an essay on the Mind; one on the Senses... His miscellaneous works are these. Heavenly Causes; Aërial Causes; Causes affecting Plane Surfaces; Causes referring to Fire, and to what is in Fire; Causes affecting Voices; Causes affecting Seeds, and Plants, and Fruits; three books of Causes affecting Animals; Miscellaneous Causes; a treatise on the Magnet... [1]

6.6. ...In general everybody was superficial except for Democritus. It seems he took care of everything; therefore he differs from everybody else. [18]

6.7. The reason why his predecessors didn't come to that (scientific) method was that they didn't know what being was, or how it was defined. The first one to tackle this was Democritus, not because the science of nature needs it, but because he was sparked by the thing itself. In the time of Socrates, philosophers paid attention to the virtue useful for life and politics. [2]

6.8. By understanding atoms as the matter of the body, he derived everything else from their changes. [2]

6.9. Those who accepted atoms thought that they should stop at the bodies not compound of parts, and that there was no infinite division. [2]

6.10. In general view, it is color...sweet...bitter, but, in fact, it is atoms and emptiness, said Democritus, who claimed that all qualities of senses, which concern us, which we notice, come from binding of atoms. However, nothing is white, black, blue, bitter, or sweet. The expression "in general view" means the same as "in general opinion" or "as far as we are concerned", and not in nature of things themselves, for which he (Democritus) uses "indeed" - "ETEIN", which he derived from "ETEON", meaning truthful. [13]

6.11. He (Democritus) simply considers soul and mind for the same because for him it is truthful (only) what is shown. [3]

\subsection{Democritus' small world system}

according to Diodorus of Sicily [2]

6.13. He didn't call veins those (blood vessels) which are usually called that, but also arteries. Democritus also calls the artery movement "vein pulsing". [2]

6.14. (On wavy and caterpillar-like pulse), as their names suggest, is characteristic that waves that come one after the other, are created in the "wavy" one, and the "caterpillar" one looks like the movement of a caterpillar. That animal also moves like a wave is what Democritus says when he mentions animals with wave-like movements. [13]

6.15. When the womb accepts the seed inserted, and then, after it has been accepted, it is surrounded in the womb, as Democritus says, like an anchor against the tempest and disruption, and the navel (is) like a rope and ties to the fruit in the moment of creation and later when nature closes the paths of cleansing and monthly wash. [2] 
6.16. Democritus says: People in their prayers ask for health of gods, but they do not know that the control over it is in them, because they work against it with immoderation, so they are betrayers of (their own) health. [2]

6.17. Out of the ancient physicians, nobody prescribed the therapy for the disease (elephantiasis) but Temision and Democritus.

This is where we should stop with the fragments that concern Democritus' naturalistic and medical philosophy, so numerous that a large book can be written about it. This is enough to understand that he was a naturalist and a physician "par exellance", who greatly influenced the naturalistic-medical thought of his and later times, and especially our Erasistratus.

\section{Comments on Certain Fragments on Democritus}

Democritus of Abdera further developed Leucippus' atomistic philosophy, and especially his application in sense perception. He makes a difference between the things that are (compound of atoms in motion) and the things the way they seem to us (which were later called "primary" and "secondary" qualities! - shape, size and matter on one side; color, sound, taste, etc. on the other). Glen explained it best. The problems of earlier scientists explained Simplicius and Aristotle who clearly singles out Democritus from other "superficial" scientists. Democritus scientifically described in his Little World System the generation of the Solar system, the Sun, the Earth, living beings and man, so I want to refer the reader to reading this fragment in afore mentioned work of Diels. His medical philosophy had influence not only on his pupil Hippocrates, but also on many latter naturalists like Aristotle and Teophrastus, the philosopher Epicurus, as well as the physician Erasistratus- to mention only the greatest. Not only was he the first one to describe elephantiasis but also, according to Erotianus, the thing of special interest for us, blood vessels, "he didn't call veins only those (blood vessels) which are usually called that ("let-off veins"), but also arteries ("inlet veins"). Therefore, Democritus called the artery movement vein pulsation ("inlet"), which is clearly pointed out by Galen in his work on pulse. Democritus clearly describes different kinds of pulse (e.g. "caterpillar-like), "wavy", and the research on pulse and these differences have always been a "trademark" of physicians. His (Democritus') comment on strengthening of the fruit in the uterus represents an exciting testimony on the knowledge of gynecology and obstetrics. After all, the mere fact that he was mentioned by Soranus, the greatest gynecologist of ancient times, is very meaningful. I do not intend to analyze his entire biological-medical philosophy and work here, but only to point out his influence on his scientific descendants. [13,7]

In conclusion, Democritus broadened medicine as a physician, and, as a biologist, through his atomism, influenced the forming of Erasistratus' cell theory. This theory, over the Roman period, as solidism, came to Galen. After its life of a half a 
millennium it was forgotten only to "recently" be discovered, at the beginning of this century.

In the end, it should be remembered: "To cure a dead man and reprimand an old man is the same thing!” (Democritus)

\title{
Physicians-Contemporaries of Erasistratus Who Influenced Him
}

\author{
Cleombrotus of Keos \\ (Ioulis, Keos, $4^{\text {th }}$ century B.C.)
}

He is primarily significant as the father of famous Erasistratus. He was a physician at the court of Seleucid I in Antioch. His eldest son, Cleophantus, was also a physician.

\section{Cleophantus of Keos \\ (Ioulis, Keos, $3^{\text {rd }}$ century B.C.)}

He is primarily significant as the brother of Erasistratus, even though he was himself an outstanding physician, surgeon and gynecologist, and also a pupil of Chrysippus. Like his brother, he founded a medical school in Alexandria in the time of Ptolemy II Philadelphus, which was primarily gynecological. He is famous of his efficient treatment of febrile illness. Galen mentions him in connection to the cure for phlegmon and eczema around anus area. Only two books of his work are mentioned 'On Wine Dosage' and 'Woman' in eleven volumes. He dealt with problems with sterility and pregnancy complications with first-time mothers, according to Soranus of Ephesus.

\section{Metrodorus II of Chios \\ (Chios, $4^{\text {th }}$ century B.C.)}

A grandson of Metrodorus, a physician and philosopher- Pythagorean of Chios (therefore "II"), and a pupil of Chrysippus of Cnidos, more famous as a husband of Aristotle's daughter.

\section{Rezime}

Erazistratovo učenje ima brojna ishodišta: (1) Alkmeonov eksperimentalni pristup anatomiji i fiziologiji; (2) Heraklitovo učenje o kretanju kao svojstvu života; (3) Leukipov i Demokritov atomizam kao osnova ćelijske teorije u biologiji i medicini; (4) Anaksimandrovo učenje o evoluciji; (5) Empedoklov koncept krvotoka, reanimacije i njegove filozofije medicine; (6) Anaksagorina filozofija medicine; (7) Medicinska učenja Erasistratovih neposrednih učitelja: njegovog otca (takođe lekara), Metrodora iz Atine, Hrisipa iz Knida, Herofila iz Halkedona i Praksagora; (8) Aristotelova i Teofrastova biološko učenje i njihova metodologija; (9) Epikurejska filozofija; i (10) poslednje, ali ne i najmanje važno, mehaniku 
aleksandrijske epohe Od svih ovih uticaja, detaljno je analizirano prvih sedam, pošto su oni neophodni za razumevanje Erasistratovog rada. Ostala tri su prevelika za ovaj članak, pa upućujemo čitaoca na relevantnu literaturu.

\section{References:}

1. Лаертије Д. Животи и мишљења истакнутих филозофа [Lives and opinions of eminent philosophers]. Београд: БИГЗ; 1973.

2. Diels H. Doxographi graeci. Berlin: 1879.

3. Aristotel. Rasprava o duši [On the Soul]. Podgorica: Oktoih; 2001.

4. Платон. Федон [Phaedo]. Београд; 1983.

5. Платон. Тимеј [Timaeus]. Београд: БИГЗ; 1976.

6. Аристотел. Метафизика [Metaphysics]. Београд: Култура; 1971.

7. Diels H. Die Fragmente der Vorsokratiker (Griechisch und Deutsch). Berlin: 1903.

8. Платон. Гозба или о љубави [Symposium]. Београд: Народна просвета; 1939.

9. Aristotle. History of Animals. I-III. Harvard University Press; 1965.

10. Aristotel. O rađanju životinja [Generation of Animals]. I-IV. Beograd: Paideia; 2011.

11. Platon. Kratil [Cratylus]. Zagreb: Studentski centar Sveučilišta; 1976.

12. Aristotel. Retorika [Rhetoric]. Beograd: Plato; 2000.

13. Galen. On the natural faculties. I-III. Chicago: W. Benton; 1987.

14. Adler A. Suidae Lexicon. I-V. Leipzig: B. G. Teubner; 1928-1938.

15. Rasel B. Mudrost Zapada [Wisdom of the West]. Zagreb: Mladost; 1970.

16. Aristotle. On Breath. Cambridge, Mass: Harvard University Press, London: W. Heinemann; 1957.

17. Aristotel. Fizika [Physics]. Zagreb: Globus, Liber; 1988.

18. Aristotel. O nastajanju i nestajanju [On Generation and Corruption]. Beograd: Dereta; 2016.

19. Aristotle. Problems, Volume I: Book 16. Cambridge, MA: Harvard University Press; 2011. 20. Aristotle. Meteorologica. III. Cambridge, MA: Harvard University Press; 1952.

21. Aristotel. O delovima životinja; O kretanju životinja; O hodu životinja. [Parts of Animals; Movement of animals; Progression of animals]. Beograd: Paideia; 2011.

Received: 07/07/2018

Reviewed: $16 / 07 / 2018$

Accepted: 24/07/2018 